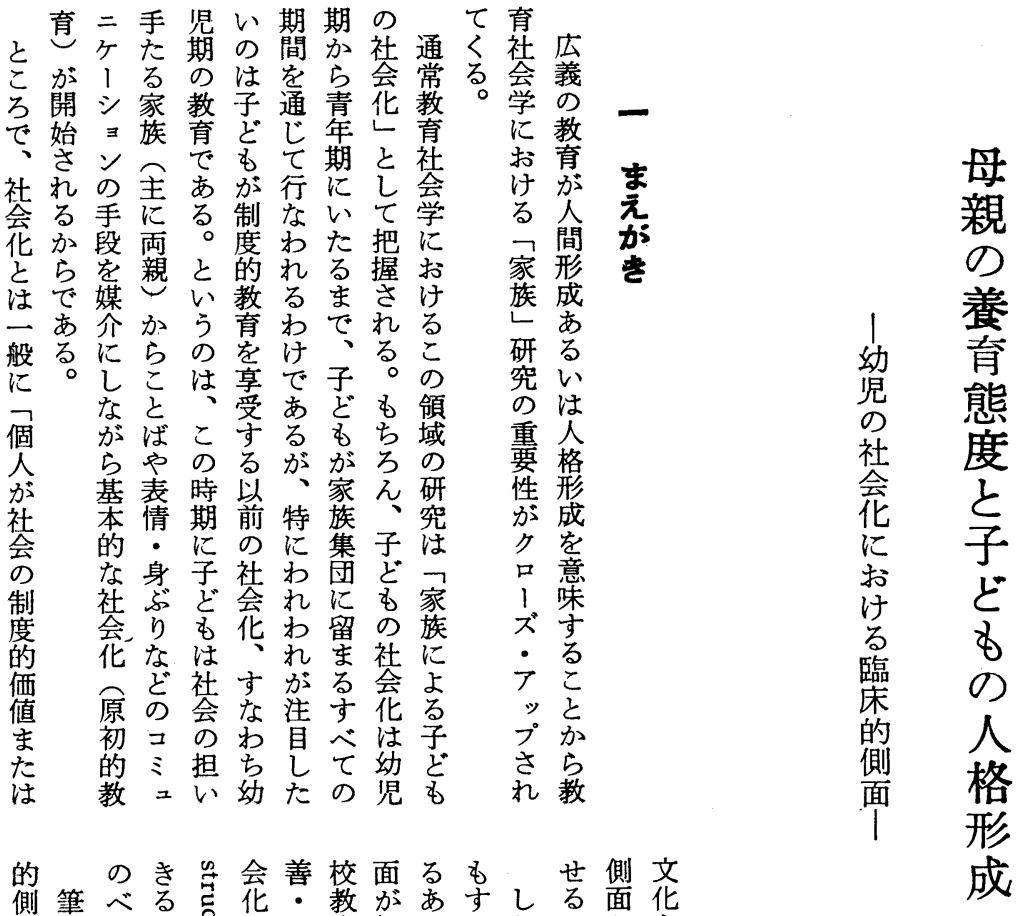

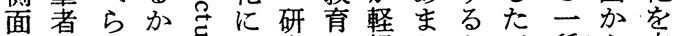
の注れ。亭つ究に視りとが種ら内 解力てレさいに打さ、社っのみ面 明ウもとをて多いれ社会て社る化

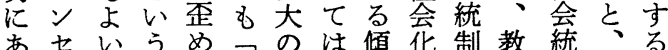
たラのよなどェ、きの作充制成過 つ1でういのネ子交主用社作人程 てとはなでよルどな体と会用世艺 力乞な社適うギもい者し学々代で 1てい会切に、のとたてにみ市あ ルのか化なすが内はるの打な若る - 経。の社れ注的い子社いすいと

口験臨会ばが心えぞ会てこ世さ

1 床化子れ理な子花社と代れ ジら的をどて構いの過会がにる +こ 側なとい造。パ程花で働が ズの 面しもるに制 のをきき

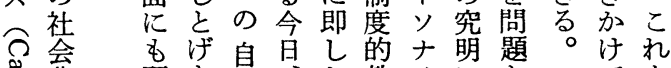

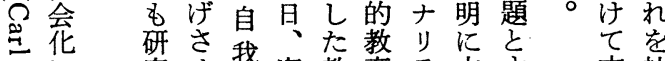

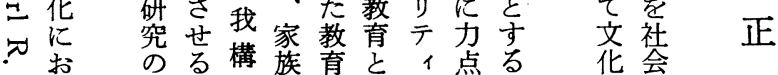
宁け手こ造に方しの点場を等 る がとな法て内置合翼機

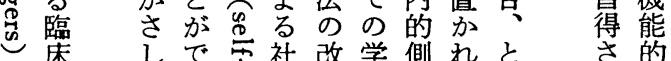




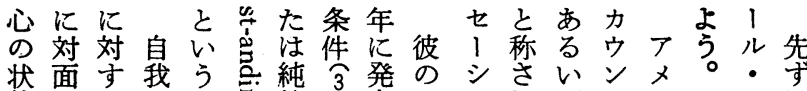

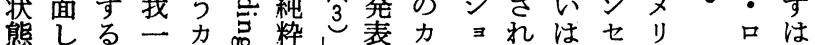

でたう致ウ等性しウンるクリカ

あとそ市ン(3) のたンをカランの

るき偽るセ無吅中员巻ウイグ著

にりいラ条异に建りきンエ経名

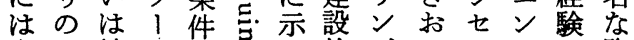

自な純のの嵒さ的グこリトの臨 我心粋助積要九理しン中中床 防純性力極氠て格論たグ心か心

衛粋之的的

㦣ない態尊

な熊う度重共

认度のに重共㤎核

自ではか感(1)起を

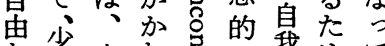

な少力わ兄理我めて

純な另方言解致必文

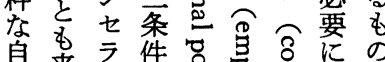

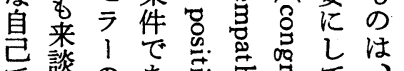

で談の要究壳

离者自量

得导息惫总

要
西

分杂
論的父学

創畐デ劣

始害乎

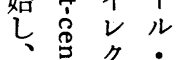

乙营产品

分递午 1

野力 $\stackrel{+}{*}$

にウ 导 ズ

き七玄

な少長
理的 5 理
ジじ

$+k$

の本

パ 研

1 究

ソ の

ナ 仮

リ説

テ設

1 定

理 上

2ิ 重

をな

要 鍵

約

的な

的要

述行

ベい

み力
一の考の

応人六

研格る 1

一 究形より

結成うナ

果ににリ

研孞になテ

究安関 1

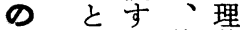

目まる彼論

的 つ寒の

た証理有

の的論力

で研にな

以究基手

下をゔが

气進い加

のめてり

概て在

要き親与

をたの元

報。養る

告そ育の

しし態で

たて度は

いことな

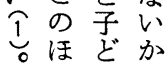
ぞをと

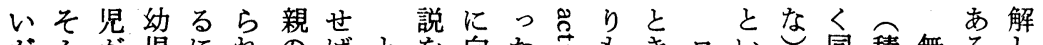
がえが児にれのばと范向た壳もき口い心同積無るし共

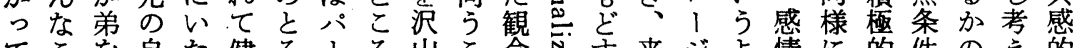

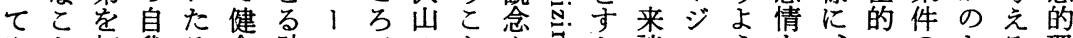
やと打我る全助ソでのとや品よ談ヤうを、、のよる理 らをつっのな力ナ、実が抑方者でなも彼成積う、解

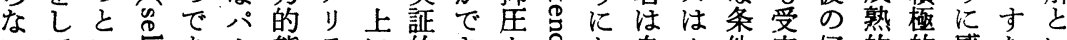
いていまあ、態テに的きを吊な自力件容好的的感ない ᄂ

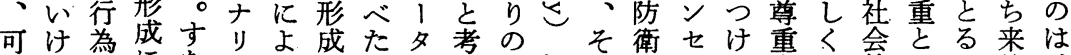

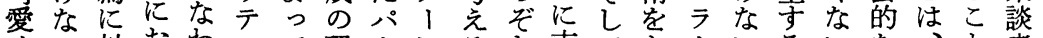

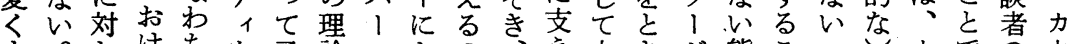
も。しけちを子論ソよの齐本きが態こっだのウ なそてる、発どとナっでパら来は右度と苦感ウあ気ン い九舟只展すなりてあ、れのなのででし情ンる持セ

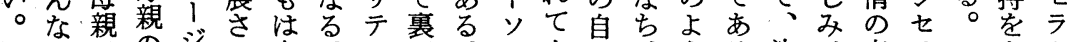

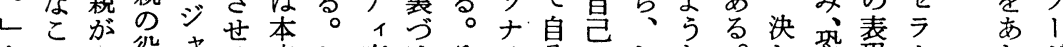

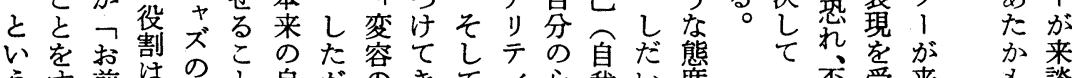

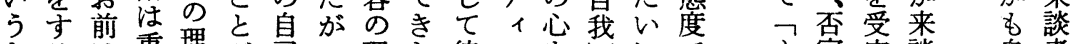
よる性重理が芑っ理た彼のを定容談自者

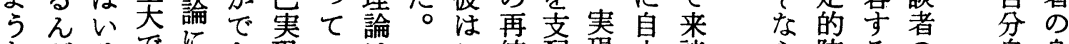
なだけでにき現口注こ統配現由談ら防るの息身 二っなっう傾 1 の合し傾な者認衛の好身に

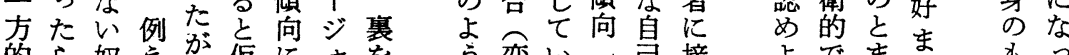

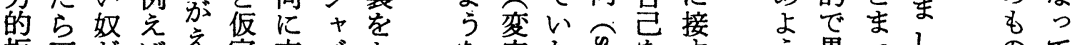

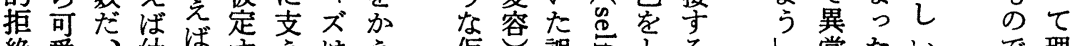

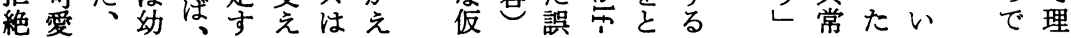




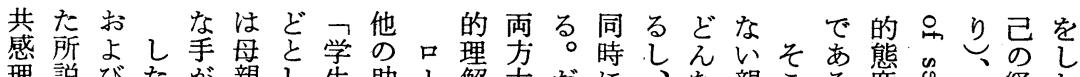
理説びたが親し生助 1解大だに、な親こる度恕自経た

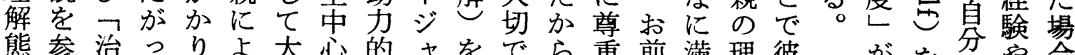
態参治っりょ大心的っをでら重前満理彼 度考療てをるき授関ズ理あ私し另足想注 こにおわ与子な業係の論る法た満を的

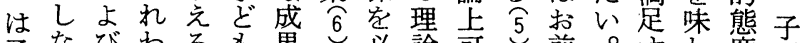

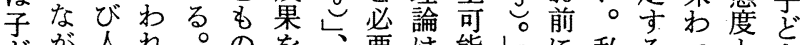
ぞが人れ。のを、要は能しに私るっとす

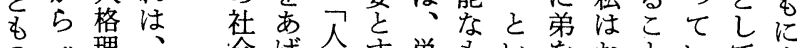

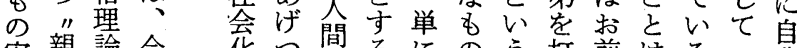
安親論今华つ祭るにのう打前注る戛

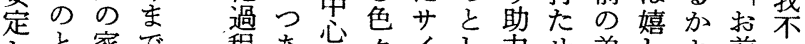

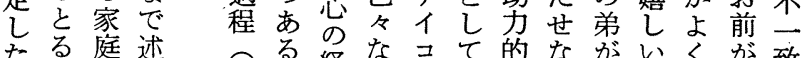

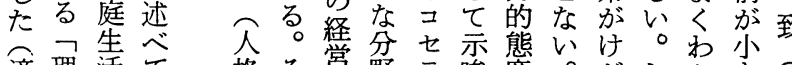
適理活 て 応解へき 的的のた

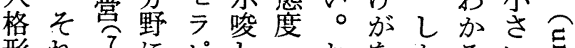

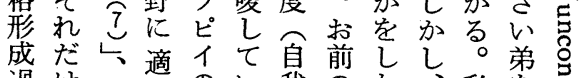
な養応パ 䏍用 ! パ態 $\widehat{9}$ ソ

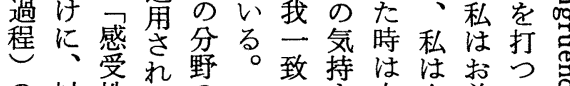

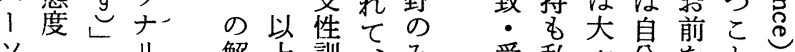
ソ 解上訓、み受私変分をと

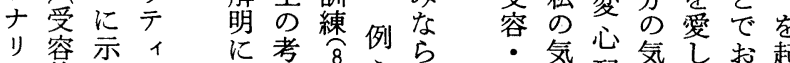

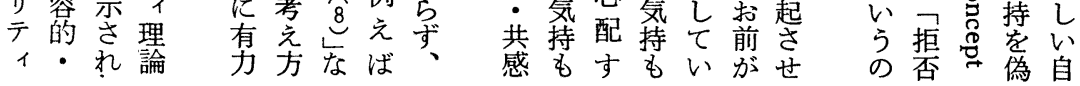

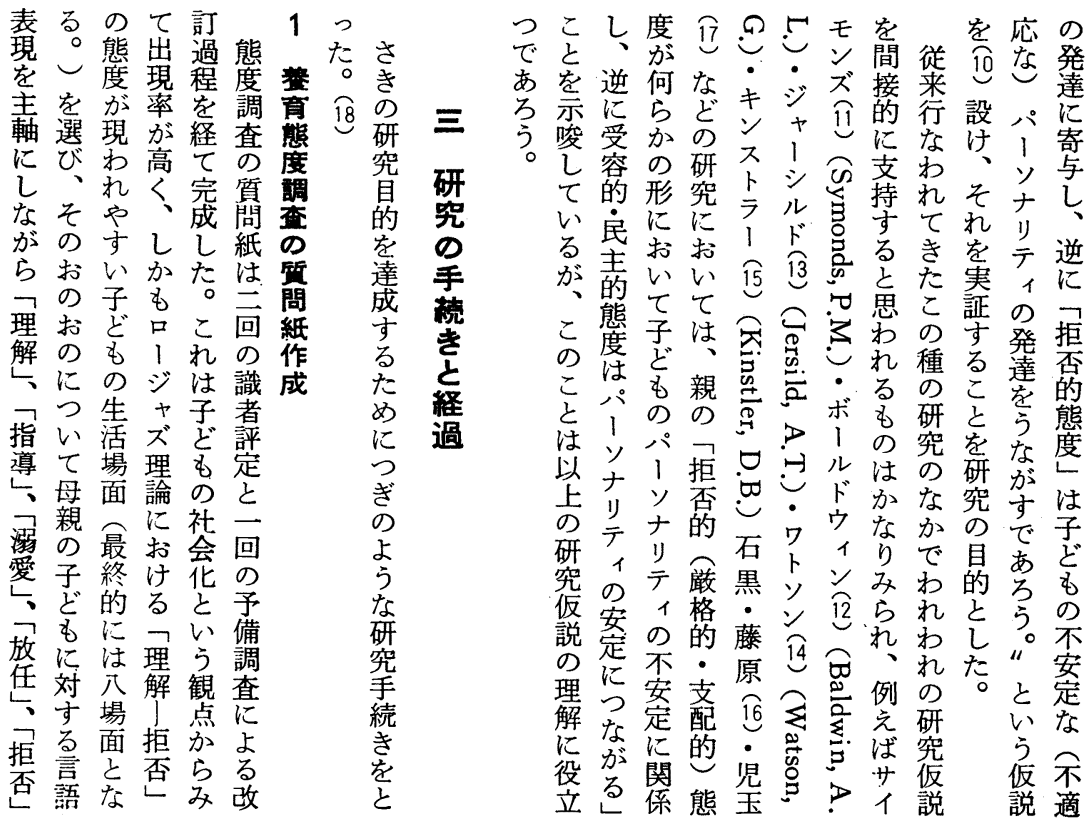


型チ型導な二的解なは

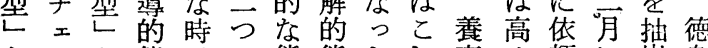

2 業他は㿝質い

とッと態例の態態たれ育く頼に出島年親なケひ問う

乙ク乙度例力度度。ら態回・加し市育命のり月紙五

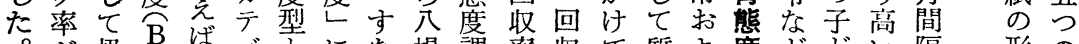

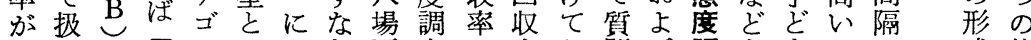

分いレᄀリし六わ面查はすおお問び調をすこで式態

散、へ理1て

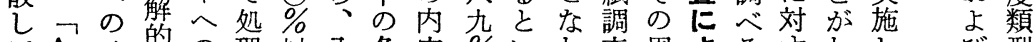

て $\mathrm{A}_{\mathrm{b}}$ 千的の理以八各容\%いわ查周よるすおし び型

態型土熊于し上場力はでうれ学辺る基るかた態に

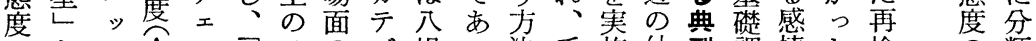

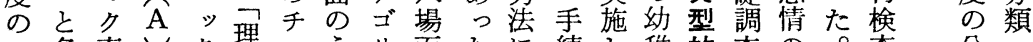

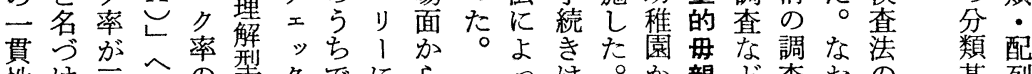

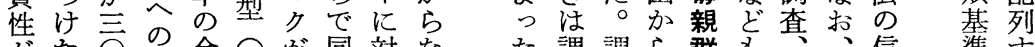

がた ○合へが同対なた調調ら群も具信準す

み。\%チ計刑なじすっる。

らなあッが型さカるて前期児理加庭の係

れおるッ六しれテ紙間の解しの質数

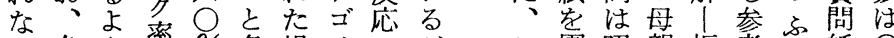

い各う率\%名昜りのが

も杂な罢以引合! 割合

のゴ合\%をたこ例に態

はり注\%な。和えよ型

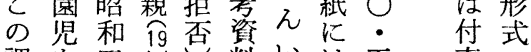
調学四包料い吾を

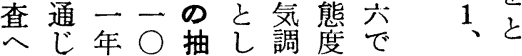

不へ混でるま学ばっの

定の合指う、型理行定

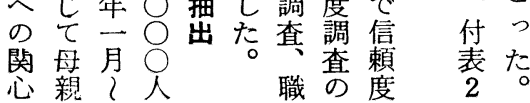

軸一た向、僅 的際 あ

四りあの自も親

での

3 六選

と致六がかににっ面○のと扱然っと面あ母こ

なし七強し判おた接分時整いにて自接る親の

って名いか断けがに前間理方表い由监のかに調

ていのとみしる、よ後を用、出くに方と面查

いるう判らた母そっで要紙家さう話法い接の

るこち断れ。親のてあしに庭れかしはうし主

母と五さなその後親っ中記管るの合子妥てな

親が二れかの態家のたに録理子钼うど当本目

態わ名るっ結度庭態

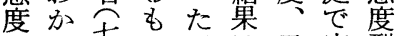

のっ六の架は子寒型

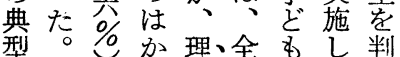

型しにな媓全もし判

たつり的典扱子生

令がいの傾型いぞる

はしの告点它性当的

時。䚄に心う養確理

間面、対に形紊加解買

を接調すと变問め的問

超時查るめと題るな紙

え間者態てっやこ親調

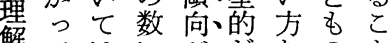

解てはにが、だなのと

群、態の強とどパ

、本度ぼいい兴、非

るはに度おて子とで査

場自対やき行ぞであに

合由す感ななるあるよ

もなる情自わのるかっ

で話態さ苖れ性。佂

拒調調りあえもと常

渠查查、るる参ナに

否研の実い考り图

群究結際はうにテ難

の果に拒なしイな

の- 六調否母再検作

たし度らなた格

が合なに話がな

平のぞ子じ合調に

ま抽

平の均た観も合調に

た出

哲柰た

すめ察のの者い的典

容のぼし傾、合ので

れかし実中济て

な型

ばなた際に前安親群

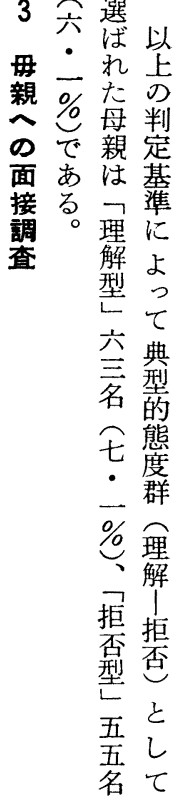


たいで口公

表 1 調 查 対 象

らと主 ジとこ

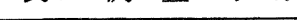

き全至れ郎

や公クる注花

くるはへ活

田系

対象種别

態度

子こき法面詫 ス

母親群

理解稀

子どす群

24

\begin{tabular}{|c|c|c|} 
拒否群 & その他 & 計 \\
\hline
\end{tabular}

\begin{tabular}{l|l|l|l|}
24 (9) & $26(10)$ & $5(2)$ & 55
\end{tabular}

ぞのりでの間

※カッニ内の数字は女子の数

す検しる圈らると

現泩认。開い検乃

実場るし幼発わ

像面之か児にれ

(a) 查な

4 調致とわど

象るへは は調の主只 表查莒之理

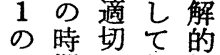
之期で親傾 お以あ中向 り昭る心の 認いしになる幼評度も定ど手いでがパよ

木知うC 提るし児定かの

ン吕点 $\mathrm{A}$ 示す

ネ容で T し の

晹はにてで

よな、比度太

りだきべ応太

理にろ場求花

想防質面め花

像衛問構る子

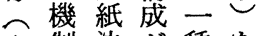

タ制法が種を

テがに明の.主

の㸺定らパ

性実調 1

格施べソ

診しるナ

断たたり

検 め テ

查诰特

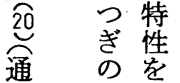

通称严衣

で和。の強

あ四考以

る 三立舟

マは近確ブ人太太方

当順 る

のを。調そソに

ハ述つ查れナ゙時はリて

ナよ等表テ热

シ。の舟市調さ

テ ハ䅐欄のた

検 $ソ$ 查に対母

查大交象親

な归加群

び テはぼなな

で 親

二 支群

月的お

四䢃ざ

年格只

年的拒

月 $の$ 的

頃 ぞ傾

ま导向

で ᄂ 強

調 評母

查 価 親

質不フ依れけ紙

問安個学存るる形

項定人校性の子式の

応るラ布う応え結係反存うしエ

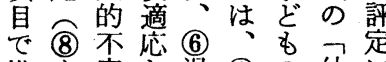

(b) 語。ス专に語ば果梨抗的にてさ

学 2 るな学名的配不が

に合 1 飞 $\tau$ 点つ量弟と活しな出

構 安な退 (1) の幼によ的参イにい基の华関い動た個さ

成 (定ど行頭性児用るに照ナなる準場さ係う的。所れ

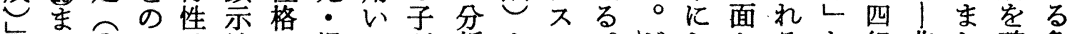

ので (1)二(7)性行児たど析ま 2 だしかるな組非た確危

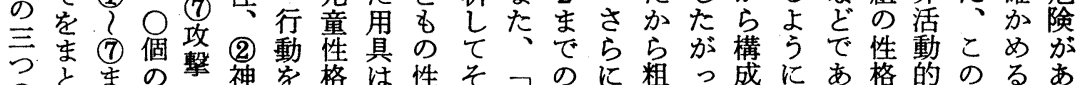

のとまの等を格は性そフのに粗っ成にあ格的のるあ

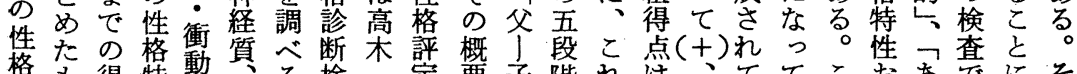

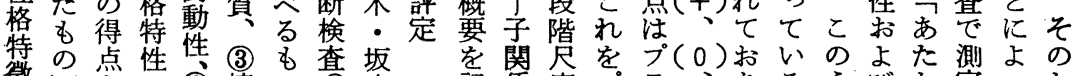

嚄しをで 8 情の 21 本

を安あ社緒でしら

とフとる会のあでに

ぬ身め方性萣る。゙よ

ら的をこ (9)性こ主て

て不のれ家穴作 る安しら庭 (4) 検し成

を関照をプ(0)打いのよた测よの 記係度プラ、りるうびた定った

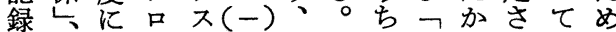
寸換 フ 3 のそ例性父いれで調

る母算 1 、以の光格、るき查 よ1す、マずそば特子つ内るの う子るルイれれ活性関め容だ直 に関よでナかぞ動に係たはけ後 な係う示不に性つ只いフ欠に っレにす 3 評ににいユ独陷母 てななと点定つつて母立を親 いどっきま亦いいは!従的補に る注てはでるてて反子順了う面 独社さ適製で評庭た 自会ら応定に質 の的に占さおお問

。反いプ分よ反い忘関了依よ接 
群はあるそ得太 1 主母

す理のれれ郎太と親

ベ解はにた・郎し側

て群子よ結花・ての

マレあっ果子花子調

イがたて 22 子ぞ査

ナすたみ年すを結

スベかるはトス側果

傾てさと表をトのは

向プレ、 $2 \neg$ の調

にラに両打理結查手

あ ス関群よ解果結続

るの孛び群果き

。傾る通図嵒学乞

そ向特じ 1 ᄀ述の

しを性ての拒芯項

て示の好と否たに

、乙及沶群の含

両てでしりしちめ

群い、いでの考て

をる他っあ子察あ

比ののプるどにる

較に三ラ

ᄂ 対 $\overline{2}$

てしにこ

特てつ傾

に拒 い向

注否てに

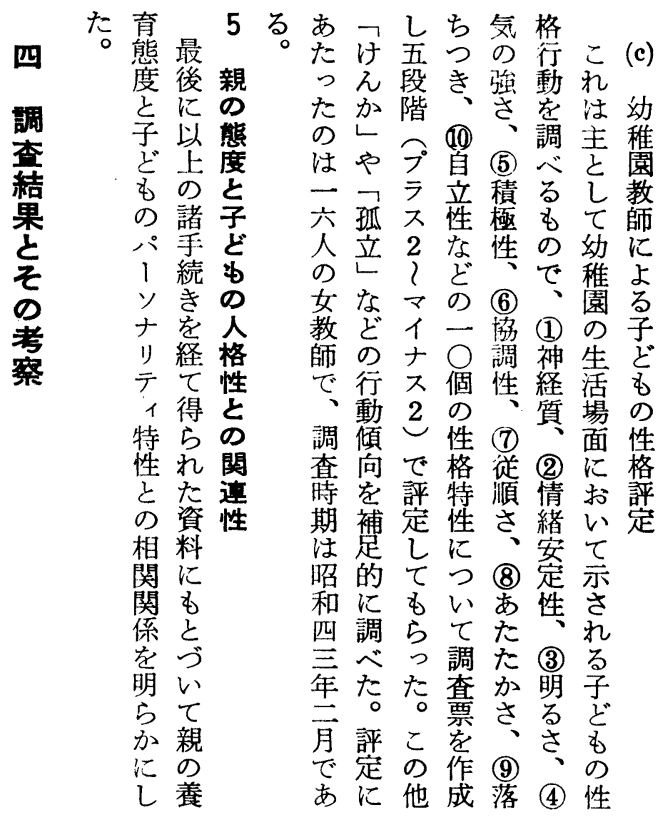

表 2 太郎・花子テストの分析結果

\begin{tabular}{|c|c|c|c|c|c|}
\hline \multirow{2}{*}{ 性格特性 } & \multicolumn{2}{|c|}{ 理解群 $(\mathrm{N}=24)$} & \multicolumn{2}{|c|}{ 拒否群 (N=24) } & \\
\hline & 得 点 & SD & 得 点 & SD & $\mathrm{df}=46$ \\
\hline 独 立 的一依存的 & +0.63 & 1.25 & -0.25 & 1.20 & $\mathrm{t}=2.39 ※$ \\
\hline 活 動 的一非活動的 & +0.88 & 1.64 & -0.13 & 1.63 & $\mathrm{t}=2.07 \%$ \\
\hline あたたかいーつめたい & +1.25 & 0.88 & +0.42 & 0.99 & $\mathrm{t}=3.01 \%$ \\
\hline 順一区 抗 的 & +1.21 & 2.02 & -0.25 & 2.52 & $\mathrm{t}=2.17 \approx$ \\
\hline
\end{tabular}

$※=\mathrm{P}<0.05 \quad ※ \%=\mathrm{P}<0.01$

図 1 太郎・花子テスト分析結果プロフィール

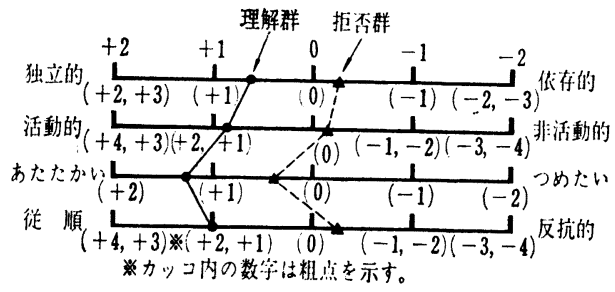


と合 撃 緒好

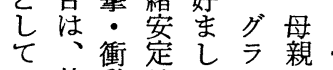
召特動性いフに

学に性亡性によ 校好学格よる 適まな特っ性 応しど比性て 格性 ᄂく学較之先評格 がなあ的しず定硳 あいげ好てフの げ特るをフ理結 ら性こし学解果 れと校群を るしがな適しま てでい応の充 依るむ六特る 存。の社をと 性一と会ひ図 上方し性乃 2 が、て牲っの 好拒㩆生孔年 を否示産るに し群性性どな

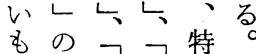
の場攻情に
2 乙おべ否群ᄀつみ分マべい度目 ていて以群し不たた類イてまパのさ

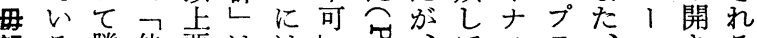
親る勝他要ははし活、てスラ、、ソきる

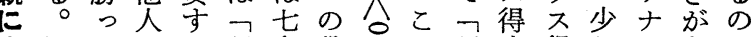
よしてにる理名段兑こ理点得しリあは とい対に解も階导で解等点整テり、

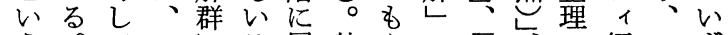

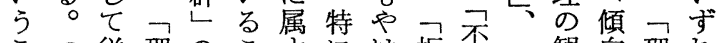
こつ従理のこ守には拒否観向理れ とを順解半とるこり否可良点を解の

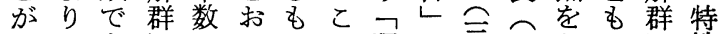
で二あしによので理の言二かっし性 き般たのしびは特解両つつえてはに る的た子か子筆群群以の卡のつつ

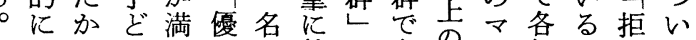
いさもたしも值の各のイ個と否て つがはなのいす方段、ナ人い群も

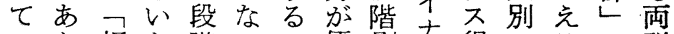
ㅇ拒と階いの優別去得のるに群 I、否いにのは征点検点比の ソ活群うあに、て出得查でべ間 ナ憅点る対 い現点、結あてに リ性のでも理る率し ᄀ果る有ほ テと子あのし解こをの可を意ほ ィ独ぞるがて群と比四こ不に一 が立も。㓅乫較段三優好段 安性に一拒でわし階つっ階

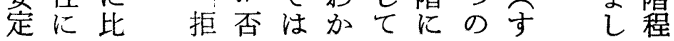

定な的1るす 性つい安セとるさ

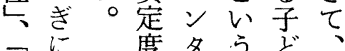
自に、度タ点を゙両 制各にルでの群 力性打段、学 ᄂ格 い階こ個比 ᄀ特てでれ人較 社性も約 は的 乙 会の両严安て 性中 群 $\overline{\mathrm{O}}$ 理定 占で 間\%解度て $\neg$ 差にの群洗 学の注開しがず 校顕約きと著目 適著四芯のしに 応な 点現間くつ レの のわに低く なは差れ得くこ どフ がて点 と で自あい热可は

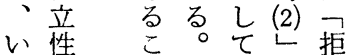
ず巟約の否 れてもた九段群 も情 見 ᄀ点階 両緒逃社恕に 群安せ会パあ属
図 2 性格診断検査プロフィール

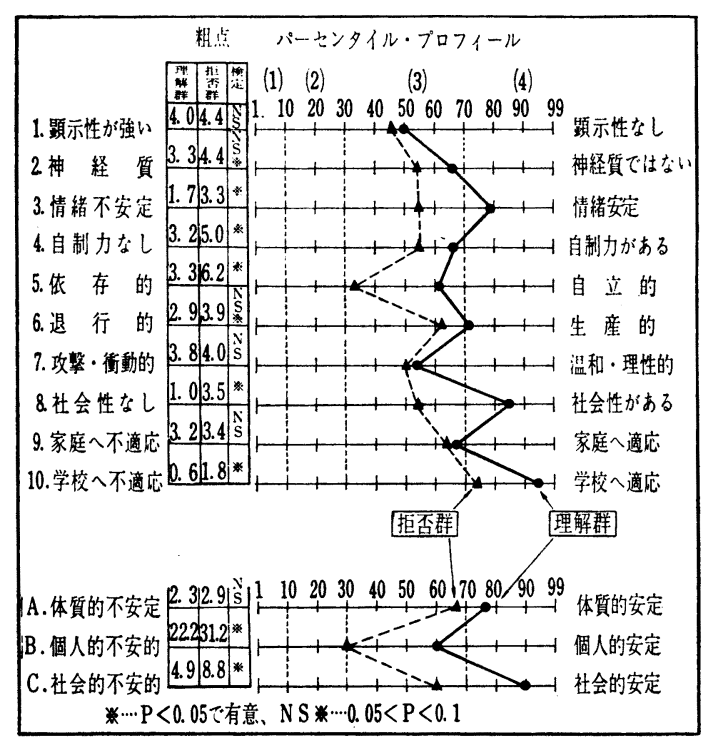


表 3 性格特徵の段階別比較

\begin{tabular}{|c|c|c|c|c|c|c|c|c|c|}
\hline \multirow{3}{*}{$\begin{array}{l}\text { 特徵 } \\
\text { 個 } \\
\text { 全 } \\
\text { 萣 } \\
\end{array}$} & \multicolumn{2}{|c|}{ 態度 } & 階 & 優 (4) & 良（3） & 可 (2) & 不可 (1) & 計 & $\begin{array}{l}\text { 検定 (優+ } \\
\text { 良) } \times \text { (可 } \\
\text { 1十不可) }\end{array}$ \\
\hline & 理 & 解 & 群 & 37.5 & 54.2 & 8.3 & 0 & $(\mathrm{~N}=24)$ & $\chi^{2}=14.02$ \\
\hline & 拒 & 否 & 群 & 12.0 & 24.0 & 44.0 & 20.0 & 100.0 & $\mathrm{P}<0.01$ \\
\hline 音 & 理 & 解 & 群 & 58.3 & 37.5 & 0 & 4.2 & $(\mathrm{~N}=24)$ & $\chi^{2}=6.21$ \\
\hline 寞 & 拒 & 否 & 群 & 24.0 & 44.0 & 32.0 & 0 & 100.0 & $\mathrm{P}<0.02$ \\
\hline
\end{tabular}

$3 て$ 安たあ的にの果いや段度的なあつれに間 い定がっで比子を以差はし不階安さりる退て比に 幼るしって自心゙要上のりて可をに定らのと行い心゙有

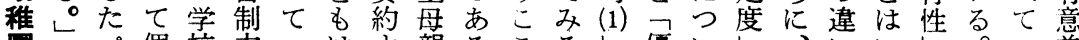

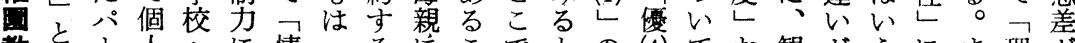

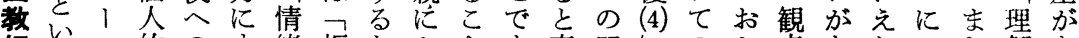
師らソ的のす緒拒なよとも表四产な点あなった解あ

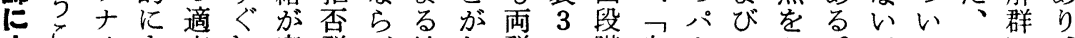

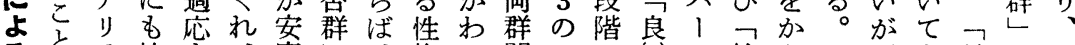

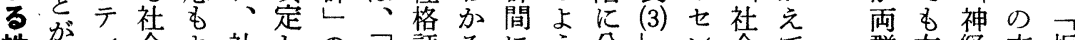

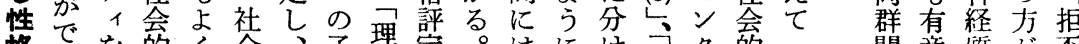

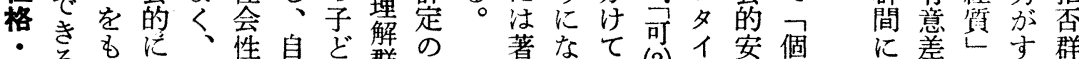

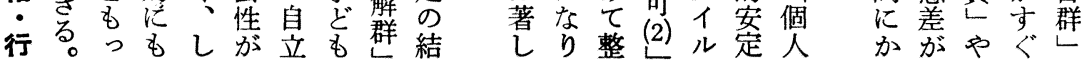

い解図すががかて 強つがた方り評さるこ段

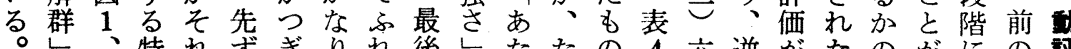
。し、特れずぎりれ後したたの 4 六逆がたのがにの評 まが図性ぞ第のちてにやただでは\%にな。よ判あ母定

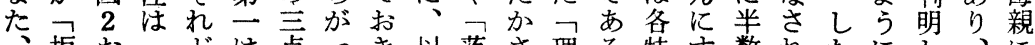
拒报ブは点っき以落さ理る特卞数れたにし、沉 太否よ自う、にてた上ち解。性ぎ以たが調て子ょ 郎群び立な三ついい述つつ群そ別な上者っ查いぞる

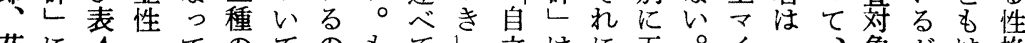
花に4 4 のてのもてし立はに五。イ二、象がは格 子比か独心検簡で占きに性居段ナ六両の、家評 テべら音る查単簃万たお拒れ階不名群園こ庭定 スてわ性か・な密え言いな否ば評評っを咱の化 卜よかしと評分な、種てど群価価理うに教りお おりる1 い定析意三のやにし両つを解う対師もい

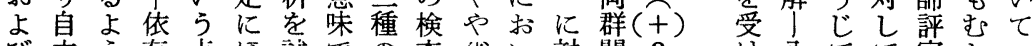
び立う存点ほ試での查劣い対間 2 け分てて定し 教的に性でぼの用・るてしに? た半全に弓学 師で、票共て関具評傾幾て顕 $(-)$ 。拒数般お学校 評あいのる通み連は定向分诸2 の否以的い校適

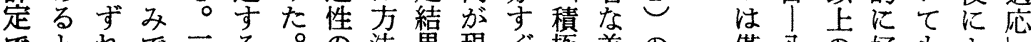
でれで三る。の法果現ぐ極差の僅入六好もょし

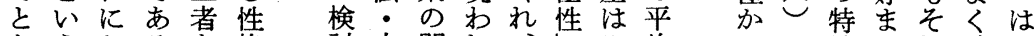
りうおる格討内関れ、实构严三性しれ適両

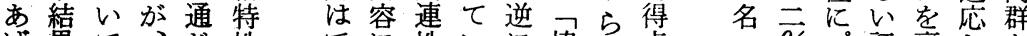

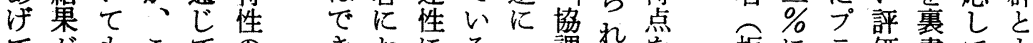

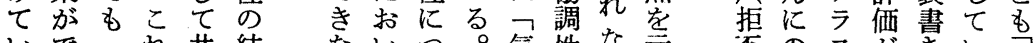

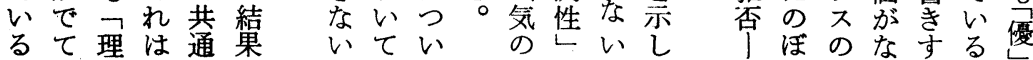


断のわこ通括年定群する従をつ さ検れれ、孤第必宓視方り順与反 れ查るは覀に要親方とむしえ抗 る・のパい入はでのが市しある性 も評で、しれ、あ評良ころるがし の定、ソがて三る定好のフい、注 を結つナ三括がと苼自は内親 プ果ぎリ者いの、教が性制つ容の ラにのテ間て検こ師みに力わを評 スつよ1でう查このらつしが検定 (十)いうのぼそ它で評れいにま討に てな安れれ゙評は定るて対ましお ᄀ手定ほ飞定あと。応してけ どど順性どれにまのそ主劣のみる ち台でと二小おり間の者る意る一 らら分い致荃け複の他間特味之攻 かか析うし査る雑諸太に性で、撃 ととし点て 評諸に特郎はと、こ。 いいて柋い評特な性。大みここ衝 ええみ重る是性るに花体るれた動

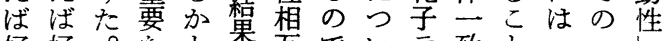

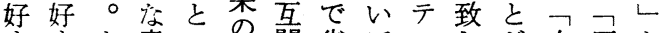

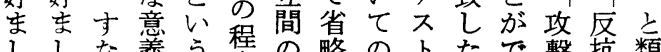
ししな羲う程の略のトたで撃抗類 くいわを点度相し細々傾き性性似 な。ちもで良違たか教向る乣し 表 4 教師による性格行動 評定

\begin{tabular}{|c|c|c|}
\hline 特性 & 理解群 & 拒否群 \\
\hline 神 䅅 質 & +0.38 & +0.42 \\
\hline 情緒安定性 & +0.46 & +0.48 \\
\hline 明 るさ & +0.42 & +0.44 \\
\hline 強 & +0.21 & +0.35 \\
\hline 榡 極 性 & +0.17 & 0.0 \\
\hline 協 調 性 & +0.5 & +0.31 \\
\hline 従 順 さ & +0.58 & +0.54 \\
\hline あたたかさ & +0.63 & +0.46 \\
\hline 落ちつき & +0.04 & +0.15 \\
\hline 自 立 性 & +0.46 & +0.31 \\
\hline
\end{tabular}
いレ々つあいをいい師不々とはた

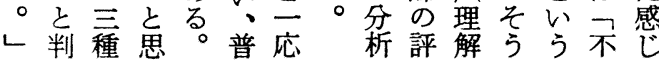

\section{し判種思普応析評解うう不し}

咅拒安加まは評 名拒安加し、価こ に否定え群るる゙こ ぎた と立致貫先 なの寒属致性卞

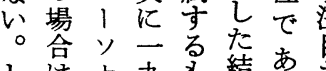
しは落ナ九結あさ是る か、名名果るれ

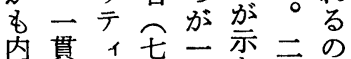
容性を九一さ六は 的老方名杂名理

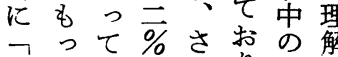
ニって\%さおす解 一評るのに、三群 一価こむ加名に

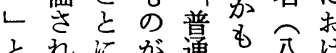
々れ核通无け むる格の+辛 好 の。的 ᄀ + 五 1 まがこに○レ\% ソ し半れ問 ○としナ く数に題 $\bigcirc$ いのリ なの対のしうもテ い一しな型好の 1

さをらす果と 以れ調のベの判 上るべ型て関断 の場ての好連さ

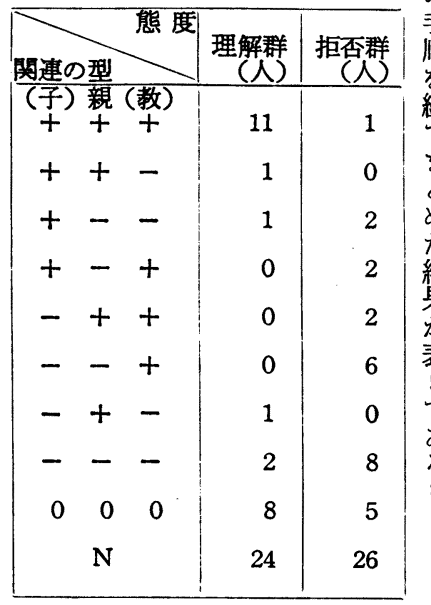
手合み出ま性れ 順はた現しにる 范二率いつ す 経 $0 \frown$ がいの て 0 なつ判てを ま0お理断いマ とし三解さくイ 者型れつナ たとのつるかス 結し結拒 と 果て果否き型の が類がしはを索 表別ほのつつつ 5 乙ほ両 + くに でた一群 +り大 あ。致別 + 別 るし琴に别例别 24 七゙型党て 普なな产検 通っる者查 といし結 評 判るそ笨定 断かれが結 
なの検っ方由るう行ててのま群のの差親親特れ型型 わ違查て法来評に動こた結れにさちがにに第徵へはに ちい・い、掟、のこ研果ておてにみよょ”とて僅入 它評て内ると太无で究といけ、詳らるる注い士かる

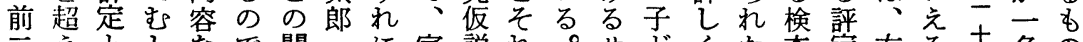
三えとしなで間花に家説れさ゚ザくた查定右る型名の 者た後ろどあに花つ庭はらなンも考の・間の。型だが

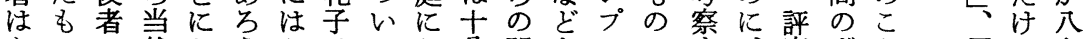
主っの然おうかテて扮関をルパ守定ずとで名

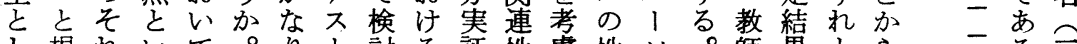

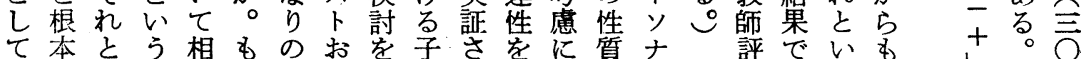
家的のこ違ちずよ加ぞれ総入和 庭な間としろれびえもた合れ必テ に相にもてえが母てとと的てずィ 打違は考い、み親み幼いに、しに けが、える三ら評た稚う判以す対 るみそらの種れ定い園こ断上理す 子らうれでのたの。にとすの想る ぞれいるあ検。結さお拉る各的他 もるっるる查こ果きけでと分での ののたしがのとにるきき!な要 生で方から評ず幼明子る、ソい因 活 場なや、定はは園加も 面い内前結そ一教にと かか容三果れ体師しの ら。な者孞ぞ何にた性 彼すどの違れによよ格

れリン影 わテプ 響 れイルや の調が母 た查 含 親
定注うわ

で点か

は理でる

そ解あよ

れ江る

艻拒态

ら否 郎 郎

れ

な両花花

以群子子

○の テ テ 間 ス

こにトト

の有おお

点意よよ

はなびび
型ま分

をこ\%

もでも

つはあ

छ) 視

が親 好

多教恏 い師 し 間 分のᄀ 名 評 + 価 + の の+ も ず レ

まに父析形かいが間付きうれ要れにいたは異ら た親 S ・成な子顕にけいいる因る過るち新子いなの か注君考上りし著あらでっこがか保子はしどるっ性 畐せ会。察重み幼でまれあたと子も護ぞ様いも。た格 男き社 5 を大ら稚ありてろ变でぞしのを々地が生行 がり員才加なれ園るずおう化あもれ下はの位家活動 早で。光こるで。れり。はるのなでさ心・庭場を くあ父はてとのはす注令よ。性い䏍し理役を面評 生る个三みとでつななっ回りこ格。っろ的割離の定

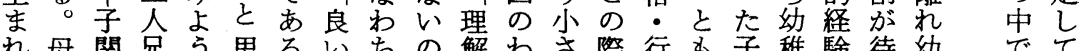

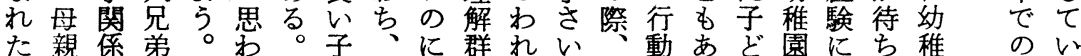

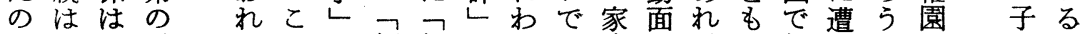

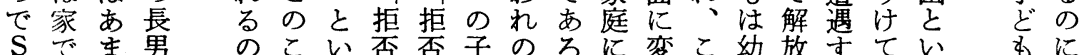
君珠りででとう群群ど調うお化う稚感るおうのの対

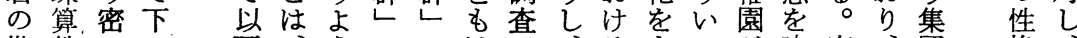

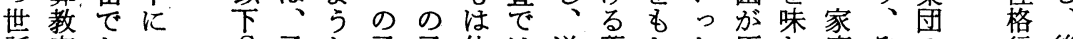
話室な二 S子な子子他は逆養たた压わ庭その は丟くつ君ど三どどのこで充ら社力うをれ中 あ開子ち まいぞが り $\tau$ \& でかのの きな世弟 なり話 肪 か多はい っ 忙 母 贯

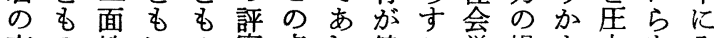
事の性にの定点れ健こ学場も力在入 例 パをは場とがば全と的所しのめる で 1 も家合教は変では・とれ場ぐと 具ソっ庭は師っ花あ当心しな所っき 体ナたで評きはれ然理てい兴認じ感子そ

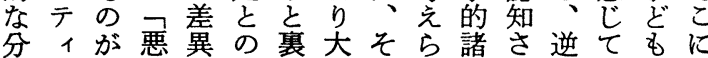
行 後 動 者 がは 評主 定に の 幼 対 稚 象 園 な $\sum^{2}$ 


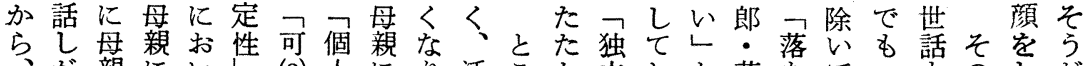

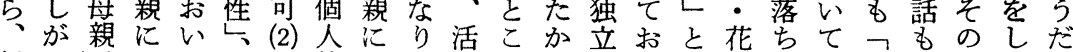
録でがはてつ的よ、発ろさ性りい子つきやな 音き迎こ依の安る小さがしし、うテきしやく君う したえん可存段定性言が、はと調のス六神し性らそ たなになし性階度格もな母 0 查でト一好経、幼めえ テえ来一以以にし評多く親と従者幼は自ま質先稚しな

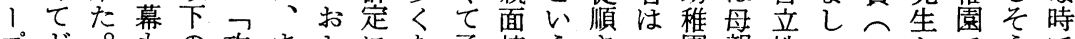
プど。すの攻まよにな子接うさ園親性い文かでうで をうそあ段撃たびおるぞの具しいでがし評イらはにも

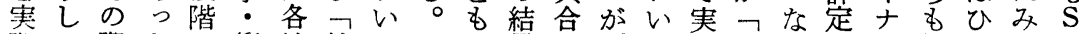
際て際たに衝性社てレら果にプ子施こどがス好よて君 にも母。ラ動格会はとしで良ラレしの沙 1 からい游 聞信親幼ン性特的極いさは好スとた子プくこれきた決

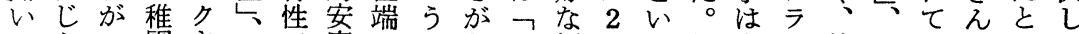
てらユ園さつで定にこなこ傾、う検家ス特ついもいて もれあでれ社も度悪といの向佸印查でのに孤るのう直 らなののて会そしいで、子染活象のは評立。で。接

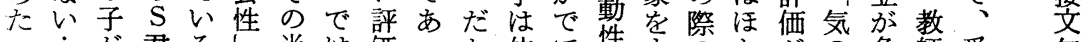

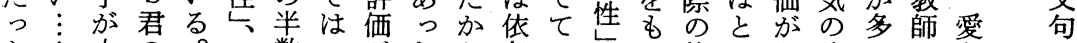

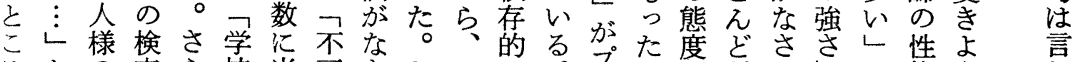

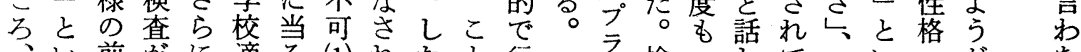

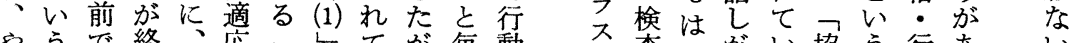

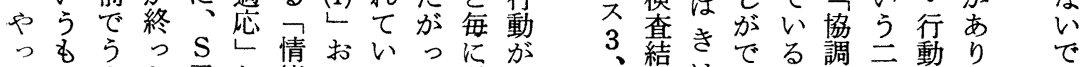

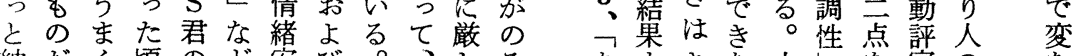

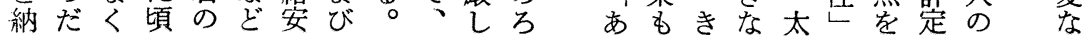

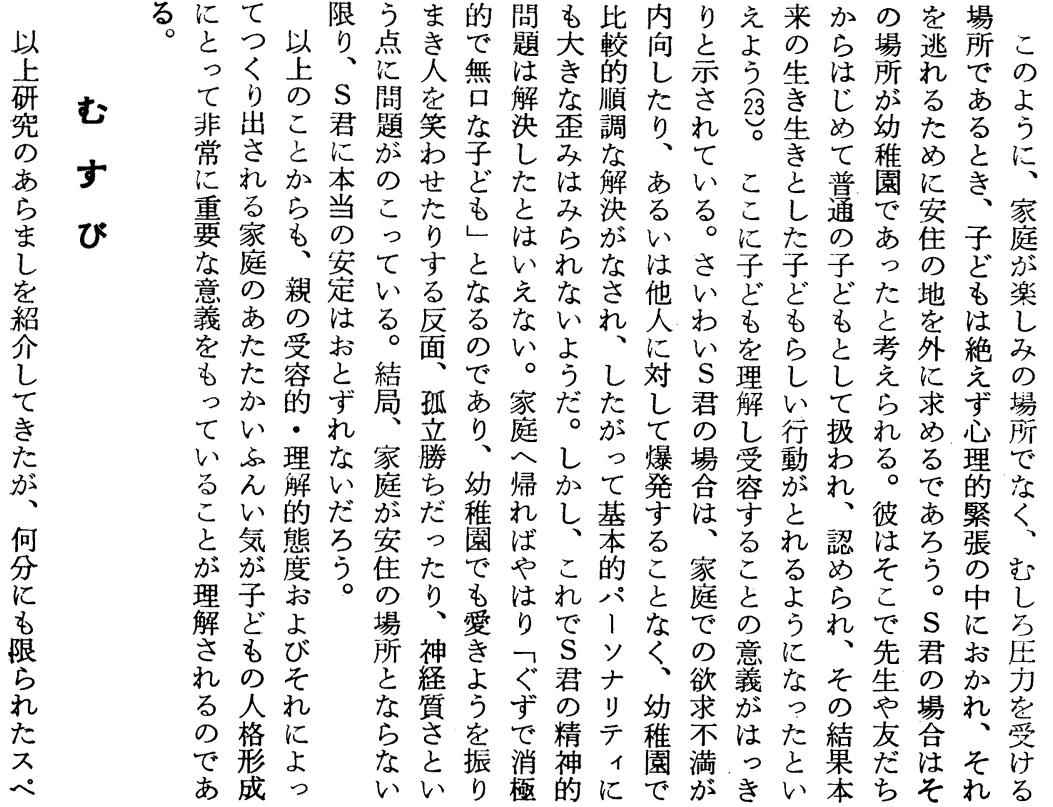

年

t

何




\section{母親の養育態度と子ぞもの人格形成}

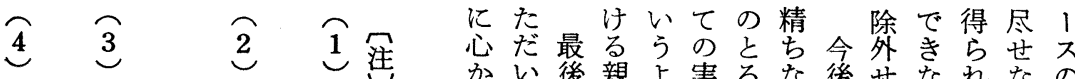
力誠伊要々こへこ

了信東定理れ各れ ル書博第論に個注

- 房訳 一につ研筆

口・編一つい究者

1 - 巻いて党者

ジ一カ・ては交昭

十六ウ一七拙付和

ズ।ン九中論に四

著二七六国基二

友七ン・四・

思貢グ四国 $\mathrm{R}$ 研兰

不の八教・究年

要 理 | 充口成度

男論五学!果策

訳恕会 济の文

人第頁編 概 部

格章詳教の希采

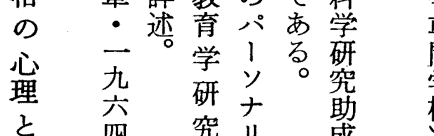

之教公究少盛

かい後親よ実るな後せなれなの

らたに子う証養ケはざかたか中

の各本関に的育 1 本るっ知っに

謝幼研係調把態

意稚究の查握度・究得。澏点

を園を発詨、唯スになま興も年

表のす達象他子夕おかた味あ間

し先す的の方ぞデけっ深るの

て生め特年ですイるた研い。研

方方色令はに柊デ。究も特究

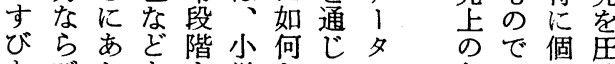

とびたをを学なて、色あ々縮

しにっ究引生る学尔っのし 阿に調て朚き感様基 なたケて

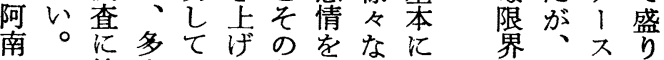

工協大以、親ひ社し やこの込 劦のきそ頪き会て 問こ分え さ便たれ中お炛、題で析だ れ宜いぞ学こ場一点はやた たを。れ生す面方等ふ比め

学 色注

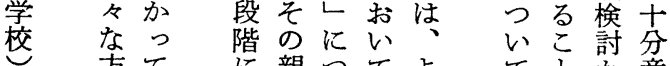

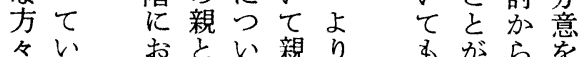

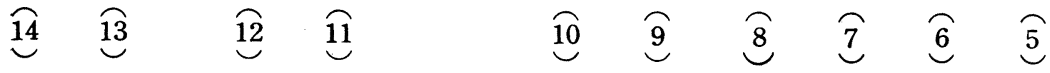

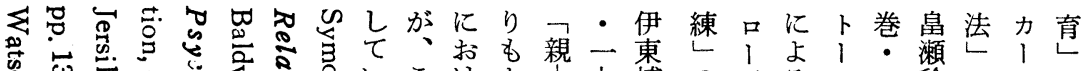
㟧

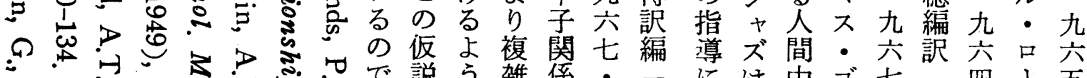

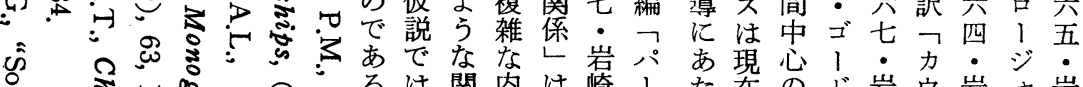

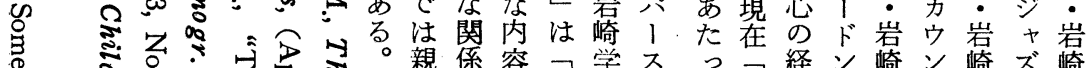

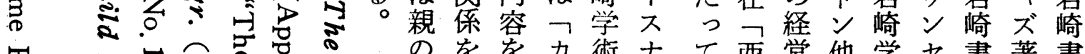

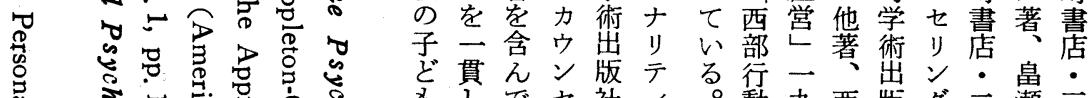

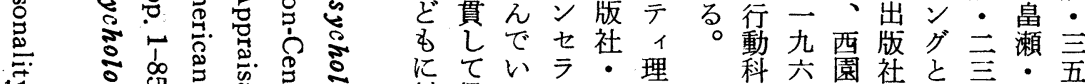
永

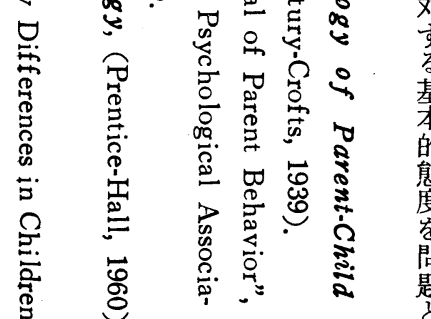
す持の|五 哈 るす基る常 ラ頁 学七持 - 教五阿 | 研 究岩郎七訳广口訳交

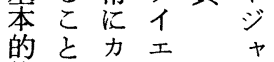

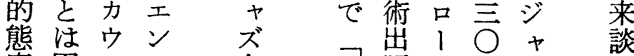
度困ント 全感版ジ頁

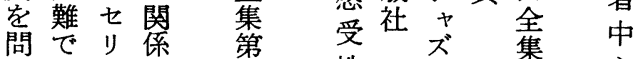
題あシ公性理第心 とるグよ巻訓論五療 
2120

19

$\stackrel{18}{17} \quad \underset{ }{16}$

15

高図依だつの調

采書田汃直年查年葉育葉

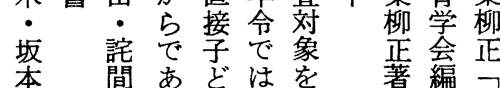

本間あどは

幼幼る。文を゙和

児児尔園

の I 坚

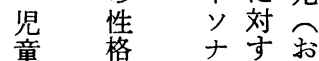

著編 -

親教養

の㕕態

養学度

等研調

性壃当る

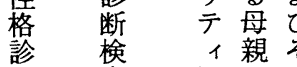

断查测筧糸

検 解 定影母

查説穾響親

手一施孞に

引厹交比限

一六交的定

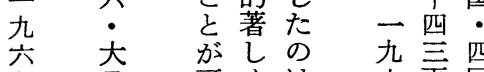

七 杲 能各气妾頁国

態究 査

度 紀の

研 要 尺

究卌度

調第化

龺 二

報巻い

告・て

書四 ᄂ

ᄂ 一 中

たこ厹児号石む。

手四省一告 こ。

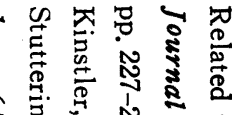

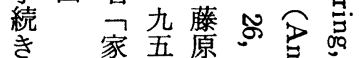

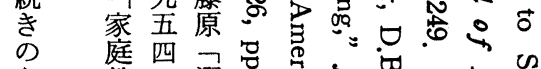

5 教四察

5 育金愛念五

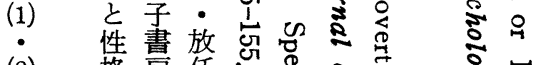

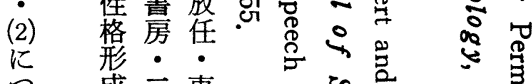

成三専

て

装家児

記科三童

文学吾怘

辨第頁理

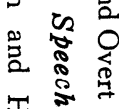

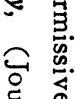

で四第

詳䍜分

述集巻

$\overbrace{24}^{23}$

$\overparen{22}$

め分花拒調、理乙金

、析子否た查イ法こ

そにテ群た者ナをで畫

れはスのかのス沙

ら使卜調い印の部表

它克查心象符改挍

をなお対のに号変よ

含かい象持よをしび

めってのちれ久図

てた言う主ばれ従老

処が名ちで

理、の、君元

しこ回母るのた反本

たこ答親。担。抗

で炎評任

守

犕㳊先特た

概な招生性內

略点、注に依

の㤎て非つ田

傾あ一常市。

向り名行堒

を理 プ間

知詳态解六占

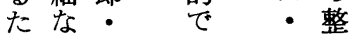


母親の養育態度と子どもの人格形成

付表 1 養育態度分類基準

(A)一理解型(A型) （子供の気持を共感的に理解し、受容する態度。親が自分の気持の表 現に忠実で正直である一純粋。)

（B）一指導型(B型）（子供に対して理解的、受容的な面もあるが、説得的、指示的、訓戒 的色彩が強い上うな態度。)

（C)一溺愛型(C型）（いわゆる、甘やかし、溺愛の熊度、子供の言いなりになったり、子 供にこびたりする態度、愛情表現は強いが必ずしす理解的といえない 面をもつ。)

(D)一放任型(D型) （子供の事にあまり関心を示さず、なげやりで、放任的な態度。）

(E)一拒否型 I (E型)（子供の気持を全然理解しようとせず，子供に対して冷酷で、過度 ※ に支配的であったり、侮皳的であるような態度、子供に拒否された気 持強(与兄引。)

（F）一拒否型II（F型）（子供の気持をあまり理解しようとせず、親本位の考えで、感情的 ※ にロらるさく子供倿する態度。支配的で、E型ほどでないが捍否さ れた気持を子供に与える。)

(E)、（F）は便宜上二つに分けたが整理段階では「拒否型」として統一した。

付表 2 質問紙（態度）の例

場面(8)

子どもが何かがおもしろくて、場えばテレビが面白くてなかなか貫ようとしな いようなとき

A 略

B 子どあに対してどのような態度をとっていますか(とりますか)。(一つ選択)

(1)「「○ちゃんは堅い子だったね、そんな堅い子が夜ふかしなんかしていいのかしら？ も3他の子は皆寝ている頃よ、そりゃね、テレビす見たいだろうけどね、子どすの夜ふ かしは体に悪いのたから早く浸てちょらたい。」といららうな態度をとる。

(口)「○○ちゃんはテレビが面白いので、まだ寝たくないのね。お母さんすあなたのテレ

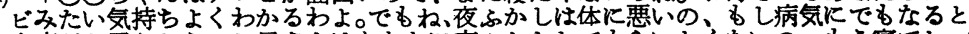
大変だと思らから、拇さんはあなたに夜らかししてもらいたくないの、るう寝てね。」 というふらな態度をとる。

(け) 子どあにあまりかまいたくないし、とやかくいってもしかたがないので、テレビが見 たければみたいだけみせて眠くなるまで自由にさせておく。

(二「○○ちゃん、お願いだからす5寝てちょらだい。こんなに遅くまでテレビを見てい て病気にですなったら大变、さあ寝㕅まで二諸についていっでけるから寝てちょらだ い。贀くしているとね、またいいのの買ってあげるからね。」というらうな態度をとる。

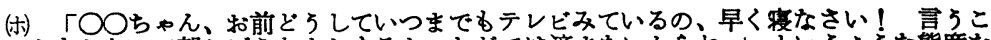
ときかないで朝ねぼうなんかすると、ただでは済まないからね。」というふうな態度を 々る。

(へ「○○ちゃん、また寝ないの、こんなに遅くまで起きているのはお前だけたよよお母 さんはそんな悪い子は嫌いよ、さあ早く赛なさい。お方んん言うこときけないような 子は何名買っでげないよ」といらふうな熊度をとる。

(卜) その他

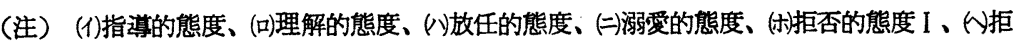
否的態度 II 、(トは内容から判断して以上のいずれかに入れる。 


$\begin{array}{lll}\text { Student } & \text { Trained } & \text { Untrained } \\ \text { Subject } & \text { Liberal } & \text { Purposive } \\ \text { Method } & \text { Modernized } & \text { Uniform } \\ \text { Family education } & \text { Prepared } & \text { Rare } \\ \text { Parents } & \text { Associative } & \text { Assistant } \\ \text { School education } & \text { Efficient } & \text { Prescriptive }\end{array}$

\title{
THE MOTHER'S CHILD-REARING ATTITUDES AND HER CHILD'S PERSONALITY
}

\section{A Clinical Aspect in Child's Socialization}

\author{
Tadashi Hayanagi \\ (Anan Technical College)
}

$\langle$ Purpose $\rangle$

The purpose of this study was to examine the hypothesis based on Carl R. Rogers' Personality Theory:

The understanding (empathic) child-rearing attitude of mothers contributes to the development of their children's "stable" personality, whereas the rejecting one to their "unstable" or maladjusted personality.

〈Procedures〉

A special set of questionnaire was prepared to find out the child-rearing attitudes of parents and used for setting a typology of their attitudes: understanding and rejecting ones. In addition, its validity was further examined by interviews with mothers sampled from the parents of kindergarteners around Tokushima City. We administered a personality test to the children, while employing two other techniques to their mothers and teachers to obtain their judgement of the children's personality traits.

As a result, we elucidated the mother's child-rearing attitudes as well as their children's personality traits. By using these data we examined correlation between the types of parental attitudes and their children's personality traits. $\langle$ Results〉

Findings in the Table show the relation between the child-rearing types 
and children's personality traits.

The Results of the Personality Test

\begin{tabular}{lccccc}
\hline \multirow{2}{*}{ Personality traits } & \multicolumn{2}{c}{ Understanding type } & \multicolumn{2}{c}{ Rejecting type } & \multicolumn{2}{c}{ Levels of } \\
& Score & SD & Score & SD & Significance \\
\hline & & & & & $\mathrm{df}=46$ \\
Independent-Dependent & +0.63 & 1.25 & -0.25 & 1.20 & $\mathrm{t}=2.39 \%$ \\
Active-Nonactive & +0.88 & 1.64 & -0.13 & 1.63 & $\mathrm{t}=2.07 \%$ \\
Warm-Cold & +1.25 & 0.88 & +0.42 & 0.99 & $\mathrm{t}=3.01 \%$ \\
Obedient-Disobedient & +1.21 & 2.02 & -0.25 & 2.52 & $\mathrm{t}=2.17 \%$ \\
\hline
\end{tabular}

$※=\mathrm{P}<0.05 \quad ※=\mathrm{P}<0.01$

The children reared by mothers of understanding type are significantly judged to be more active and independent, more obedient and warm to others, i.e. have stable personality compared with those whose mothers are of rejecting type. According to other techniques, the similar tendency was found although the degree varied.

In short, we may conclude that the hypothesis stated in the beginning has been supported.

\title{
The Problems of Independent Farmers Course of Agricultural High Schools
}

\author{
Issei Tanaka \\ (Meijo University)
}

We have two problems in relation to this subject. One is how to teach the village youth the agricultural techniques after their graduation from high school. The other is that of employment of such youth. As regards the first problem, agricultural high school students should be provided with special advanced course or institutions even after graduation, because technical education at high school which provides only elementarv knowledge and techniques, is not sufficient to manage agricultural work for themselves. To master the techniques that raise the production, they must learn many production techniques for another some years.

Nowadays, the graduates learn them through Four-H clubs, prefectural 